\title{
From Donor to the Lab: A Fascinating Journey of Primary Cell Lines
}

\author{
Magdalena Richter ${ }^{1 \dagger}$, Oliwia Piwocka ${ }^{2 t}$, Marika Musielak ${ }^{3}$, Igor Piotrowski ${ }^{3}$, \\ Wiktoria M. Suchorska ${ }^{2,3 *}$ and Tomasz Trzeciak ${ }^{1}$ \\ ${ }^{1}$ Department of Orthopaedics and Traumatology, Poznan University of Medical Sciences, Poznań, Poland, ${ }^{2}$ Radiobiology \\ Lab, Department of Medical Physics, Greater Poland Cancer Center, Poznań, Poland, ${ }^{3}$ Department of Electroradiology, \\ Poznan University of Medical Sciences, Poznań, Poland
}

OPEN ACCESS

Edited by:

João Agostinho Machado-Neto,

University of São Paulo, Brazil

Reviewed by: Keli Lima,

University of São Paulo, Brazil

Fernanda Marconi Roversi,

State University of Campinas, Brazil

${ }^{*}$ Correspondence:

Wiktoria M. Suchorska wiktoria.suchorska@wco.pl

${ }^{\dagger}$ These authors have contributed equally to this work

Specialty section:

This article was submitted to Molecular and Cellular Oncology, a section of the journal Frontiers in Cell and Developmental

Biology

Received: 21 May 2021

Accepted: 21 June 2021

Published: 22 July 2021

Citation:

Richter M, Piwocka O,

Musielak M, Piotrowski I,

Suchorska WM amd Trzeciak M (2021) From Donor to the Lab:

A Fascinating Journey of Primary Cell Lines. Front. Cell Dev. Biol. 9:711381. doi: 10.3389/fcell.2021.711381
Primary cancer cell lines are ex vivo cell cultures originating from resected tissues during biopsies and surgeries. Primary cell cultures are objects of intense research due to their high impact on molecular biology and oncology advancement. Initially, the patient-derived specimen must be subjected to dissociation and isolation. Techniques for tumour dissociation are usually reliant on the organisation of connecting tissue. The most common methods include enzymatic digestion (with collagenase, dispase, and DNase), chemical treatment (with ethylene diamine tetraacetic acid and ethylene glycol tetraacetic acid), or mechanical disaggregation to obtain a uniform cell population. Cells isolated from the tissue specimen are cultured as a monolayer or three-dimensional culture, in the form of multicellular spheroids, scaffold-based cultures (i.e., organoids), or matrix-embedded cultures. Every primary cell line must be characterised to identify its origin, purity, and significant features. The process of characterisation should include different assays utilising specific (extra- and intracellular) markers. The most frequently used approaches comprise immunohistochemistry, immunocytochemistry, western blot, flow cytometry, real-time polymerase chain reaction, karyotyping, confocal microscopy, and next-generation sequencing. The growing body of evidence indicates the validity of the usage of primary cancer cell lines in the formulation of novel anti-cancer treatments and their contribution to drug development.

Keywords: primary cancer cell lines, tumour dissociation, isolation of the cell lines, 2D versus 3D cell culture, methods for cell line characterisation

\section{INTRODUCTION}

Cell culture development significantly changed the area of life sciences and contributed to great advancements in medicine. Research with the use of cell lines is an essential procedure for modelling diseases, stem cell and cancer investigation, and the establishment of therapies (Jedrzejczak-Silicka, 2017). The first observations leading to the development of cell culture (Figure 1) were done in the 1800s by Wilhelm Roux, who maintained chicken embryos alive for few days in saline solution, thereby, proposing the principle of cell culture (Hudu et al., 2016). However, the exact primary cell culture has its beginning in the first decade of the 20th century, when Ross Granville Harrison successfully cultivated frog nerve cells by hanging drop method. For this experiment, he used small pieces of frog embryonic tissue immersed in droplets of lymph solution on the cover slide. Then, he turned a plate upside down and to great effect maintained a primary cell culture, in which he observed nerve cells and watched developing fibres (Jedrzejczak-Silicka, 2017). After these achievements, cell culture was improved by elaboration of work under aseptic conditions, which led to other discoveries, such as, the establishment of the first mouse fibroblast culture, followed by 


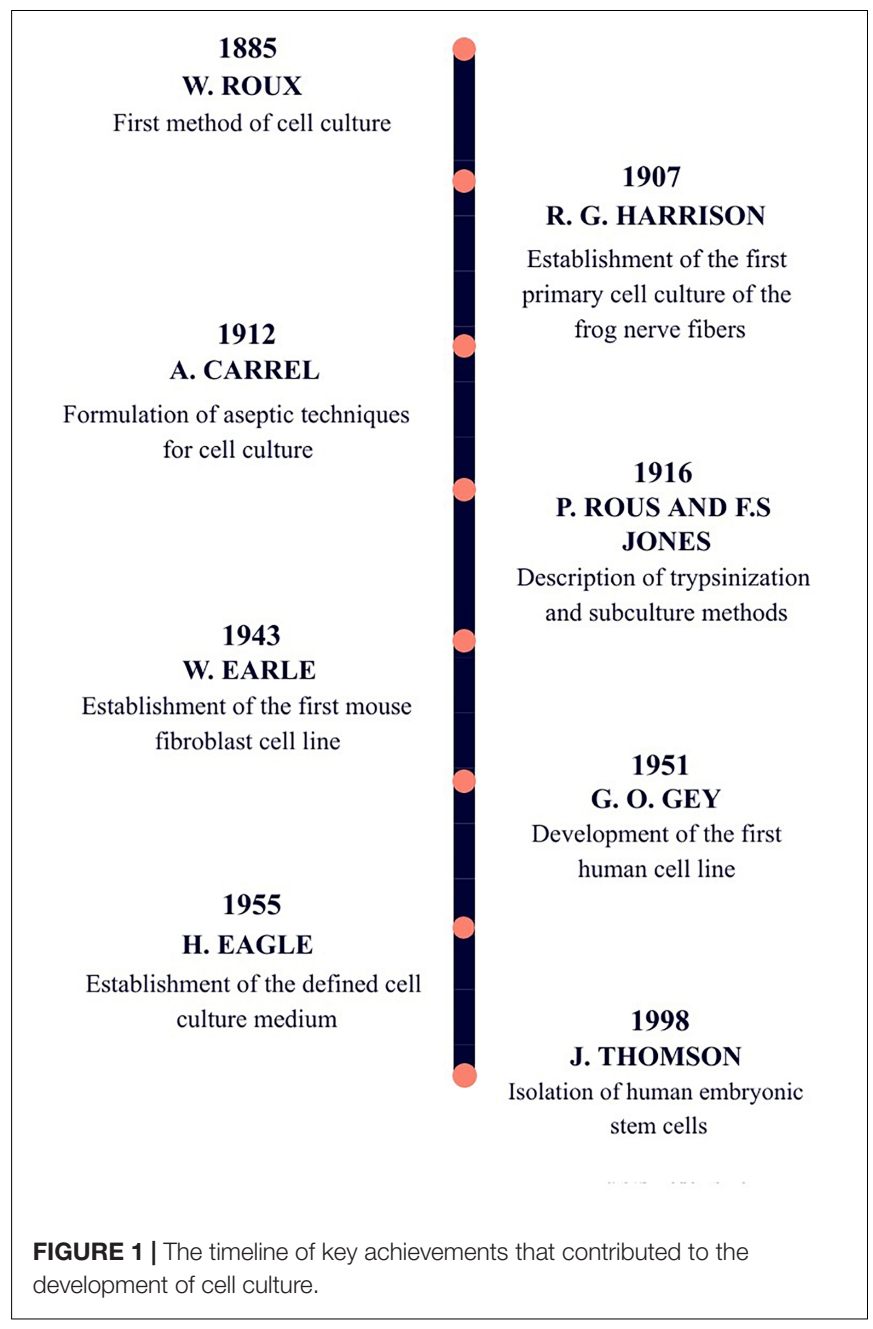

the development of the first human tumour cell line. A few years later, MEM and DMEM media were formulated, as well as media supplemented with growth factors. The last crucial event for the development of cell culture, took place in 1998 when human embryonic stem cells were isolated (Jedrzejczak-Silicka, 2017; Ledur et al., 2017).

Cell lines, as we know them today, play a remarkable role in cancer research. The application of cancer cell lines enabled a better understanding of tumour biology and improved drug development (Mitra et al., 2013). The examples of drugs formulated with the use of immortalised cell lines are trastuzumab tested on breast cancer cultures (Zazo et al., 2016), imatinib tested on myelogenous leukaemia cell line (Tusa et al., 2020) or bevacizumab used for therapy of glioblastoma (Simon et al., 2014) and non-small cell lung cancer (Lauro et al., 2014).

The main aim of this review is to present the most recent data referring to primary cell lines isolation and characterisation processes. This article highlights the variety of isolation methods depending on the cells' source and its next implementation. Moreover, we aimed to introduce different molecular methods of isolated cells' characterisation. This review is a summary of the available knowledge in the field of primary cell lines culture.

\section{PRIMARY VERSUS ESTABLISHED CELL LINES}

Primary cancer cell lines are ex vivo cell populations deriving directly from resected tissue samples, most commonly from core biopsies, fine-needle aspirates, pleural effusions, resections, or autopsy specimens (Kodack et al., 2017; Miserocchi et al., 2017). These samples can reflect the tumour's natural microenvironment and preserve characteristic crosstalk between healthy and cancerous cells. Those intercellular behaviours are essential during carcinogenesis, progression, and metastases, and also take part in responses to therapies (Leithner et al., 2014; Miserocchi et al., 2017). Primary cultures preserve the stem-like phenotype of cancer cells, which is also valuable during preclinical studies of drug resistance mechanisms. Ex vivo models enable accurate reflection of tumours and are more suitable for clinical analysis, in contrast to the most widely used immortalised cell lines that may not be completely predictive towards cancer expression (Miserocchi et al., 2017). Genetic aberrations of immortalised cell lines accumulate with every passage, limiting their usefulness and impacting the final overview. There is also variation in patient reactions to the same drugs used on tumours with identical genetic mutations. It is complicated to comprise all genetic and epigenetic variants' heterogeneity in millions of patients by having at disposal only a limited number of cancer cell lines. Hence, there is growing interest and need to establish primary cancer cell lines (Mitra et al., 2013).

Primary cancer cultures serve as a powerful tool for studying cancer biology, gene expression, oncogene activation, or amplification. Patient-derived specimens are useful in examining hormone responsiveness and chemotherapy's impact on tumour cells (Vázquez et al., 2004). However, primary cells have a finite lifespan and limited replicative capacity (Table 1), which leads to narrow culture time (Gillooly et al., 2012). Depending on the goals of the research, scientists should choose the appropriate model to fit the needs of the experiment. The introduction of established cell lines has led to the development of many therapies and treatment strategies. Moreover, it has allowed to work on the same lines in different places around the world. This fact is a key role in comparing the achieved results, drawing conclusions, and producing better cancer treatment strategies. Nevertheless, the short-term culture of primary cells from solid tumours acquired great importance in personalised cancer therapy (Mitra et al., 2013). Combined with next-generation sequencing (NGS), primary cancer cultures create a promising cancer treatment tool (Ishikawa, 2017).

\section{STEPS BEFORE PROCEEDING TO EXPERIMENT}

\section{Ethical and Legal Requirements in Europe}

Human biological materials are valuable specimens, widely used for studying health-related issues. These components are unique for every human and are obtained from various 
TABLE 1 | Comparison of primary and immortalised cell lines.

\begin{tabular}{|c|c|c|c|}
\hline Feature & Primary cells & Immortalised cell lines & References \\
\hline Biological relevance & Higher & Lower & Mitra et al., 2013 \\
\hline Lifespan and proliferation & Limited & Unlimited & Gillooly et al., 2012 \\
\hline Molecular properties & $\begin{array}{l}\text { Preserve characteristic cells' behaviours and } \\
\text { cross-talk between cells }\end{array}$ & Untypical cellular behaviours may occur & $\begin{array}{l}\text { Carter and Shieh, 2010; } \\
\text { Miserocchi et al., } 2017\end{array}$ \\
\hline Phenotype & High heterogeneity & Lower heterogeneity & Ali et al., 2017 \\
\hline Genetics & Original genome & $\begin{array}{l}\text { Altered genome, accumulation of } \\
\text { genetic aberrations }\end{array}$ & Carter and Shieh, 2010 \\
\hline Relevance in vivo & Best experimental models for in vivo studies & Low relevance for in vivo studies & Verma et al., 2020 \\
\hline Handling & Needs optimised culture conditions and media & Established media from manufacturer & Weigand et al., 2016 \\
\hline Ethics & $\begin{array}{l}\text { Require Ethical Commission approval and } \\
\text { patient consent }\end{array}$ & Do not require additional documents & Petrini, 2012 \\
\hline
\end{tabular}

body parts during the examination, surgery, or post-mortem. Biological materials comprise DNA, proteins, cells, tissues (including blood and plasma), whole organs, saliva, urine, faeces, and other body liquids (i.e., wound fluids). Those are gathered for different purposes: diagnosis, clinical treatment, or research (Patel and Rajput, 2019). Laboratories that possess and handle biological samples must consider numerous issues connected to bioethics, legislation, and storage. The research approach on human biological materials differs among people, thus researchers must respect and take donors' morals under advisement (Petrini, 2012).

The Clinical Trials Regulation EU No 536/2014 (CTR) modulates research on biological materials of human origin. According to those directions, obtaining biological samples must be held only with the "donors" written informed consent. Alternatively, an authorisation may be given on behalf of the donor by an eligible person or representative authority. Written informed consent should enable the right to withdraw the approval and alter the scope of the agreement. The person concerned can stipulate the use of his/her biological material and personal data at any time. However, when gathering "patients" information, it is hard to foresee the purpose and scope of personal data processing for future research. Thus, it should be allowed to consent to certain areas of study, depending on the "donors" wishes. Alternatively, it is advised to compose an additional article of the consent, stating that the donor permits to use his/her data outside of the clinical trial protocol.

Research should commence only after an independent evaluation of its scientific value, including the significance of the aim and confirmation of ethical standards by the appropriate committee [Casali and Vyas, 2021, Regulation (EU) No 536/2014] $]^{1}$.

\section{Storage and Disposal of Human Biological Materials}

Biospecimens are usually collected during surgery or examination (Patel and Rajput, 2019). For some studies,

\footnotetext{
${ }^{1}$ Regulation (EU) No 536/2014 of the European Parliament and of the Council of 16 April 2014 on clinical trials on medicinal products for human use, and repealing Directive 2001/20/EC. https://eur-lex.europa.eu/legalcontent/EN/TXT/ ?uri=celex\%3A32014R0536.
}

the samples must be appropriately preserved (Hubel et al., 2014). The most frequently used methods of preserving human biological material are freezing and storage at low temperatures or chemical fixation (Hubel et al., 2014). Biospecimens of human origin are treated as biohazardous and after used most commonly are disinfected and disposed of by incineration (Patel and Rajput, 2019).

\section{Preparation for the Experiment}

Human biological samples must be treated as potentially dangerous materials since these might be contaminated with contagious pathogenic viruses (e.g., HIV or hepatitis viruses), methicillin-resistant Staphylococcus aureus, bacteria, and fungi (Shepherd et al., 2007; Geraghty et al., 2014). For these reasons, tissue processing should be executed aseptically in a Class II biosafety cabinet. Biospecimen collection shall be performed by a surgeon and pathologist (Yap et al., 2019). Authors of research should include histopathological diagnoses, confirmation of how the specimens were collected (biopsy or resection), description of the tumour and its origin (primary tumour site or metastatic lesion), as well as procedure applied to fixed tissue (formalinfixed paraffin-embedded or frozen tumour tissue) (Nushtaeva et al., 2019). As far as possible, data on preanalytical handling of specimens should also be given. If control samples are used in research, their origin and isolation should also be noted. Besides describing the specimen, authors need to include patients' characteristics, such as age, gender, ethnicity, medical history, or disease stage. Thus it might be relevant for research as in cohort studies (Knijn et al., 2015). Also, a small amount of non-cancerous tissue should be frozen to indicate other genetic differences of a cell line and can be used in the process of authentication (Geraghty et al., 2014).

\section{METHODS OF TUMOUR DISSOCIATION AND ISOLATION OF THE PRIMARY CELL LINES FROM AN EXPLANT}

\section{Tumour Dissociation}

Techniques for tumour dissociation are usually reliant on the organisation of connecting tissue. To obtain a uniform cell 
population, the most common methods include enzymatic digestion, chemical treatment, or mechanical dissociation (Figure 2; Mitra et al., 2013).

\section{Enzymatic Digestion}

The usage of enzymes for tissue dissociation is a general procedure that enables the retainment of cell viability and integrity by concurrent decent tissue digestion (Table 2). The most widely used enzyme is collagenase; however, it can be used with other enzymes (Mitra et al., 2013). Collagenase belongs to the class of endopeptidases and digests collagen in the region of the triple helix. Collagen is the leading component in connective tissue; thus, collagenase is useful when isolating epithelial, endothelial, or adrenal tissue. Moreover, it can be applied for the isolation of adipocytes, hepatocytes, cardiomyocytes, and the treatment of mammary or other soft tissues ${ }^{2}$. The procedure of cell isolation with collagenase and hyaluronidase is also successful in breast cancer (Pandrangi et al., 2014; ZubeldiaPlazaola et al., 2015; Weigand et al., 2016). There are different approaches concerning the mixture of those two enzymes, for example, slow/fast digestion shown by Zubeldia-Plazaola et al. (2015). Their research tested the efficacy of using collagenase and hyaluronidase of different concentrations for various periods. During slow digestion, human tissue was left overnight at a low

$\overline{{ }^{2} \text { http://www.worthington-biochem.com/CLS/default.html }}$
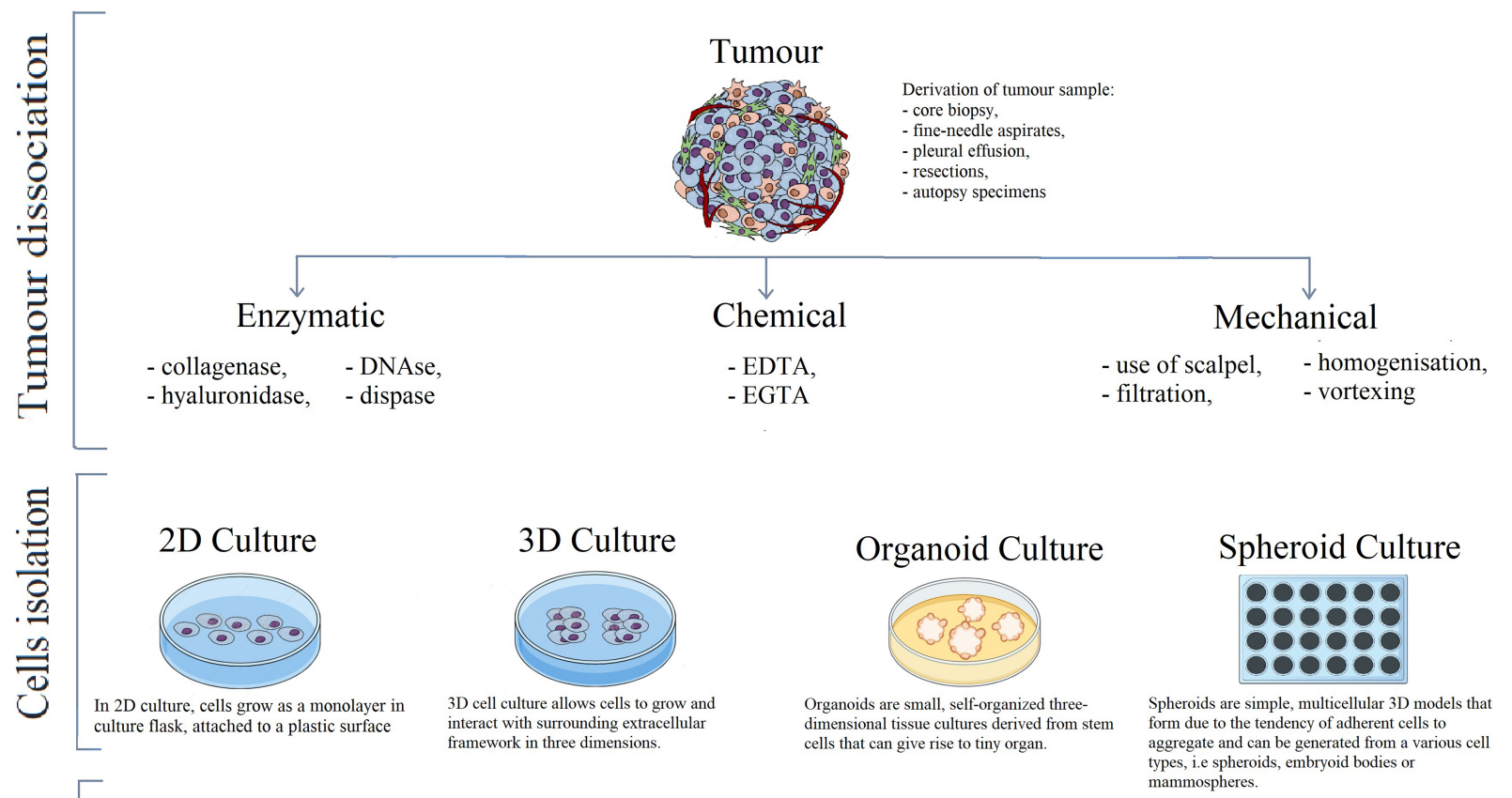

$\left.\right|^{2}$

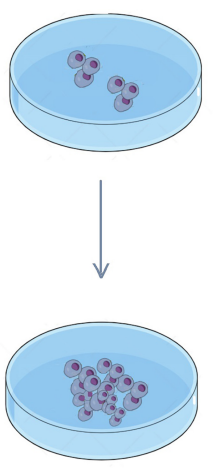

Primary cancer cells

Primary cell culture contains the cells

directly obtained from host tissue.

Expanding cancer cell culture

Contains sub-cultured cells from primary cell culture.

FIGURE 2 | Schematic visualisation of primary cancer cell line development. Cancerous tissue can be dissociated by three different methods. The enzymatic method utilises enzymes such as collagenase, dispase, DNase, depending on tissue structure. The chemical method makes use of EDTA or EGTA that causes the loosening of intercellular bonds. Methods are often combined, for example mechanical tissue disaggregation with a scalpel, followed by enzymatic digestion. Afterwards, tumour tissue is seeded onto a plate, and cells are grown in 2D culture or 3D culture, in form of organoids or spheroids. The last step of primary cell line development is cell culture in appropriate conditions and further expansion of cancer culture. 
TABLE 2 | Enzymes suitable for dissociating cells from solid tumours.

\begin{tabular}{|c|c|c|c|c|}
\hline Enzyme & Cancer & Derivation & Method & References \\
\hline \multirow[t]{5}{*}{ Collagenase } & Cervical & Biopsy & $1 \mathrm{~mL}$ solution of $0.2 \%$ type I collagenase, incubation for $1 \mathrm{~h}$ & Villa et al., 2018 \\
\hline & Colorectal & Resection & $\begin{array}{l}5-10 \mathrm{~mL} \text { of collagenase type } \mathrm{H} \text { solution of concentration } \\
1.5 \mathrm{mg} / \mathrm{mL} \text { and incubation for } 4-6 \mathrm{~h} \text { or overnight at } 37^{\circ} \mathrm{C}\end{array}$ & Failli et al., 2009 \\
\hline & Renal & Resection & $5 \mathrm{~mL}$ of collagenase solution and incubation for $45 \mathrm{~min}-1 \mathrm{~h}$ & Yap et al., 2019 \\
\hline & Breast & Biopsy & 0.2 mg/mL collagenase III solution, incubation overnight & Faridi et al., 2018 \\
\hline & Liver & Resection & Triple digestion with type IV collagenase for 5 min at $37^{\circ} \mathrm{C}$ & Cheung et al., 2014 \\
\hline $\begin{array}{l}\text { Collagenase }+ \\
\text { hyaluronidase }\end{array}$ & Breast & Surgery/mastectomy & $\begin{array}{l}\text { Slow digestion: } 1.6 \mathrm{mg} / \mathrm{mL} \text { collagenase }+0.14 \mathrm{mg} / \mathrm{mL} \\
\text { hyaluronidase, incubation overnight; } \\
\text { Fast digestion: } 2 \mathrm{mg} / \mathrm{mL} \text { collagenase }+2 \mathrm{mg} / \mathrm{mL} \\
\text { hyaluronidase, incubation for } 4-6 \mathrm{~h}\end{array}$ & $\begin{array}{l}\text { Zubeldia-Plazaola } \\
\text { et al., } 2015\end{array}$ \\
\hline $\begin{array}{l}\text { Collagenase }+ \\
\text { DNase }\end{array}$ & Breast & Biopsy & $2 \mathrm{~h}$ in $0.15 \%$ collagenase and $0.015 \%$ DNase & Meltzer et al., 1991 \\
\hline \multirow[t]{2}{*}{$\begin{array}{l}\text { Collagenase }+ \\
\text { dispase }\end{array}$} & Ovarian & Surgery & $1 \mathrm{mg} / 1 \mathrm{~mL}$ collagenase/dispase solution, incubation for $2 \mathrm{~h}$ & $\begin{array}{l}\text { O'Donnell et al., } \\
2014\end{array}$ \\
\hline & Brain & Surgery & $\begin{array}{l}0.6 \mathrm{U} / \mathrm{mL} \text { collagenase/dispase solution, incubation for } 30 \text {, } \\
60,120 \mathrm{~min} \text {, or overnight }\end{array}$ & Volovitz et al., 2016 \\
\hline \multirow[t]{2}{*}{$\begin{array}{l}\text { Collagenase }+ \\
\text { DNase }+ \text { dispase }\end{array}$} & Pancreatic & Surgery & $\begin{array}{l}1 \mathrm{mg} / \mathrm{mL} \text { collagenase, } 4 \mu \mathrm{g} / \mathrm{ml} \text { dispase and DNase } 11 \mathrm{~mL} \\
\text { or } 2 \mathrm{~mL} \text { per } 0.1 \mathrm{~g} \text { tissue, incubation for } 1 \mathrm{~h}\end{array}$ & Ehlen et al., 2020 \\
\hline & Skin & Surgery & $\begin{array}{l}200 \mathrm{U} / \mathrm{mL} \text { type I collagenase, } 200 \mathrm{U} / \mathrm{mL} \text { dispase and } \\
70 \mathrm{U} / \mathrm{mL} \text { DNase solution, incubation for } 2 \mathrm{~h}\end{array}$ & $\begin{array}{l}\text { Dallaglio et al., } \\
2013\end{array}$ \\
\hline $\begin{array}{l}\text { Collagenase }+ \\
\text { hyaluronidase }+ \\
\text { trypsin }\end{array}$ & Breast & Surgery & $\begin{array}{l}0.5 \times \text { collagenase/hyaluronidase solution, incubation for } \\
16 \mathrm{~h} \text {, then additional digestion with } 0.01 \% \text { trypsin for } 30 \mathrm{~min}\end{array}$ & $\begin{array}{l}\text { Weigand et al., } \\
2016\end{array}$ \\
\hline $\begin{array}{l}\text { Collagenase }+ \\
\text { DNase }+ \text { trypsin }\end{array}$ & Pancreatic & Surgery & $\begin{array}{l}1 \mathrm{mg} / \mathrm{mL} \text { collagenase } \mathrm{XI}, 4 \mu \mathrm{g} / \mathrm{ml} \text { DNase and trypsin } 1 \mathrm{~mL} \\
\text { per } 0.1 \mathrm{~g} \text { tissue, incubation for } 30 \mathrm{~min}\end{array}$ & Ehlen et al., 2020 \\
\hline $\begin{array}{l}\text { Collagenase }+ \\
\text { trypsin }\end{array}$ & Breast & Mastectomy/biopsy & $\begin{array}{l}\text { Incubation in } 2.5 \% \text { crude trypsin for } 30 \mathrm{~min} \text {, followed by } \\
0.15 \% \text { collagenase solution overnight }\end{array}$ & $\begin{array}{l}\text { Pandrangi et al., } \\
2014\end{array}$ \\
\hline Hyaluronidase & Brain & Surgery & $\begin{array}{l}1000 \mathrm{U} / \mathrm{mL} \text { solution of hyaluronidase, incubation for } 30,60 \text {, } \\
120 \mathrm{~min} \text {, or overnight }\end{array}$ & Volovitz et al., 2016 \\
\hline \multirow[t]{2}{*}{ Dispase } & Prostate & - & Digestion with dispase II solution & Wang et al., 2019 \\
\hline & Ovarian & Surgery & $2.4 \mathrm{U} / \mathrm{mL}$ dispase II solution, incubation for $30 \mathrm{~min}$ & Pribyl et al., 2014 \\
\hline
\end{tabular}

enzymatic concentration of collagenase and hyaluronidase, 1.6 and $0.14 \mathrm{mg} / \mathrm{mL}$, respectively. Fast digestion lasted for 4-6 h, and the concentration of used collagenase and hyaluronidase was equal to $2 \mathrm{mg} / \mathrm{ml}$, in both cases. Slow and fast digestion was then followed by sequential filtering and differential centrifugation that resulted in organoids, epithelial, and stromal fractions. This study indicates the validity of slow digestion due to the more significant number of obtained viable cells that gave rise to a better quantity of cells in culture than fast digestion. Slow digestion is a less aggressive method, thus, it is possible to acquire higher cell yield. Moreover, slow digestion followed by differential centrifugation enables more significant cell growth and efficacy than sequential filtering (Zubeldia-Plazaola et al., 2015).

A combination of collagenase and deoxyribonuclease (DNase) is effective in breast and ovarian cancer (Meltzer et al., 1991; O'Donnell et al., 2014). DNase gets rid of genomic DNA from samples dedicated to further analysis with RT-PCR ${ }^{3}$. Collagenase and DNase can also be combined with dispase to isolate primary cells from pancreatic cancer (Ehlen et al., 2020). Dispase, also called neutral protease, is a very stable metalloendopeptidase that is less harmful to cells than trypsin and prevents cell aggregation without cell membrane damage

\footnotetext{
${ }^{3}$ http://www.worthington-biochem.com/DNASE/default.html
}

(Alvarez et al., 2006). This enzyme provides delicate detachment of epidermal cells and split-up of the epidermis from the dermis ${ }^{4}$. Different combinations of enzymes (Table 1) may be used to isolate primary cells from brain tumour samples, as shown by Volovitz et al. (2016). Research throughout few enzymes (collagenase, DNase, hyaluronidase, dispase, and papain) and their combinations showed great effectiveness of DNase, collagenase, and hyaluronidase (DCH) mixture, as well as, dispase alone. The most favourable enzyme concentrations were: DNase $(5 \mathrm{u} / \mathrm{ml})$, collagenase $(0.05 \%)$, and hyaluronidase $(1000 \mathrm{u} / \mathrm{ml})$. Usage of DCH yielded excellent dissociation quality and excellent viability at comparable concentrations. However, the best results were achieved with the use of dispase. In that case, cell survival and tissue dissociations were the highest and the most satisfying (Volovitz et al., 2016). Isolation of primary cancer cells with dispase is also an effective procedure in prostate, ovarian and cervical cancer (Pribyl et al., 2014; Villa et al., 2018; Wang et al., 2019). The use of dispase enables the effective recovery of viable, fibroblast-free epithelial ovarian cancer cells (EOC). The EOC cultures achieved with dispase disaggregation are highly responsive to genetic manipulation (Pribyl et al., 2014).

\footnotetext{
${ }^{4}$ http://www.worthington-biochem.com/DISP/default.html
} 


\section{Chemical Dissociation}

The cell membrane contains cations, such as $\mathrm{Ca}^{2+}$ and $\mathrm{Mg}^{2+}$, that provide integrity for the cell surface and intracellular structural matrix. The use of chemical agents enables removing those ions, which causes the loosening of intercellular bonds in, i.e., epithelial cells. The best chemicals used for sequestration are ethylene diamine tetraacetic acid (EDTA), ethylene glycol tetraacetic acid (EGTA), and tetraphenyl boron complexes with potassium ions (Mitra et al., 2013). To isolate primary hepatocytes, EGTA is a popular method of choice. EGTA is a chelator for calcium ions that efficiently disrupts cell adhesion to the underlying matrix. Moreover, removing $\mathrm{Ca}^{2+}$ promotes flushing the blood out of tissue specimen, cramps blood clotting, and disturbs the desmosomes among cells (Bhogal et al., 2011; Horner et al., 2019). EDTA acts similar to EGTA, although it is often combined with trypsin and used during trypsinisation to detach cells from a medium and break cell-to-cell adhesion (Kurashina et al., 2019).

\section{Mechanical Disaggregation}

Mechanical disaggregation of tumour tissues comprises mincing with a scalpel, filtration through $50-100 \mu \mathrm{m}$ mesh, homogenisation, vortexing, pipetting, or application of extreme osmolarity stress (Mitra et al., 2013). The most frequently used method for mechanical dissociation is cutting tissue samples with scissors or scalpel to the size of 1-2 $\mathrm{mm}^{3}$ (Phuc et al., 2010; Ali et al., 2017; Faridi et al., 2018; Ghaderi et al., 2019). Specimens prepared this way can be subsequently placed in a Petri dish and cultured with an explant method, or mechanical disaggregation may be combined with an enzymatic process for better results (Nushtaeva et al., 2019).

Alternatively, instruments like disposable disaggregator or microfluidic device can be used for mechanical dissociation of tissue samples. Semiautomatic tissue disaggregation operates at a speed of $100 \mathrm{rpm}$, which enables tissue disintegration without trauma. It contains two elements: boreholes surrounded by six microblade, and the other is a rotating element that brings the tissue onto blades (Failli et al., 2009). Microfluidic device technology aims to improve mechanical dissociation of tissue, reduce the time of the procedure, enhance cell recovery, and increase sample purity. The device provides rapid and gentle dissociation with little or no enzyme usage. A microfluidic instrument consists of a network of branching channels that are gradually decreasing in width. The channels have repeated expansions and constrictions that cause a fluidic blow-out, providing the shear force necessary to separate cells (Qiu et al., 2015, 2018).

\section{Methods of Primary Cancer Cell Culture}

Cell culture is a commonly used tool that enables understanding of cell biology, tissue morphology, protein production, and diseases mechanisms. Moreover, they are essential during preclinical research of drugs, including cancer treatment, and conducting studies on gene function. The selection of appropriate cell culture methods may impact finding new treatment strategies or optimising existing radiotherapy and chemotherapy (Kapałczyńska et al., 2016). The cultures may be accomplished under adherent conditions when cells grow as a monolayer, attached to a glass or plastic dish, or maybe cultivated in suspension, which better reflects the natural environment. Up to this point, $2 \mathrm{D}$ cultures were the most commonly used type of cell culture, however, 3D cultures are displacing them more often (Figure 2; Jensen and Teng, 2020).

\section{D Cultures}

Cells in adherent 2D culture grow as a monolayer in a particular culture flask or on a Petri dish attached to a plastic surface. The main reasons standing by $2 \mathrm{D}$ cultures' popularity are their low-cost maintenance, fast time of culture formation, and simplicity. Despite that, 2D cultures face many difficulties. One of the disadvantages of adherent culture is its inability to mimic the natural structure of the tumour and express cell-cell and cell-extracellular environment interactions essential during cancer research. In 2D culture conditions, cells lose their diverse phenotype, thus morphology is changed what affects their functions and cell signalling. Moreover, cells in adherent culture have constant access to nutrients, oxygen, and metabolites present in the medium. In the case of cancer cells in vivo, nutrient availability is variable due to the tumour's natural architecture. Lastly, adherent culture is most commonly monoculture, enabling research of one cell type, resulting in the absence of tumour niches (Kapałczyńska et al., 2016).

\section{D Culture}

Since the 1970s in the 20th century, many researchers have contributed to developing $3 \mathrm{D}$ cell culture, so cancer studies can be conducted on this model (Penderecka et al., 2020). The 3D culture shows significant improvements in studies concerning cell morphology, proliferation, response to stimuli, and drug metabolism. These advances are possible by a remarkable feature of 3D cultures, enabling observation of cells in their in vivo conditions while being cultured in vitro. Consequently, 3D cell culture accurately mimics the cells' environment, preserves natural cell shape and growth. Cells cultivated in this model often keep cell junctions that allow for cell-to-cell communication (Jensen and Teng, 2020).

Moreover, proper cell-cell and cell-extracellular environment interactions, provide arising of environmental niches. Molecular mechanisms, such as gene expression, splicing, topology, and biochemistry of cells, are well preserved by contrast to $2 \mathrm{D}$ cultures that tend to interfere with gene expression (Kapałczyńska et al., 2016). The most common 3D models used for cancer research are scaffold-based cultures, multicellular spheroids, and matrix-embedded cultures (Penderecka et al., 2020).

Scaffold-based techniques comprise approaches like hydrogelbased support, hydrophilic glass fibre, or organoids. The use of hydrogels enables mimicking of the extracellular matrix (ECM) and free flow of cytokines and growth factors throughout the tissue-like gel. Hydrogels can be natural and synthetic, and natural ones are made with polymers, such as collagen, fibrinogen, Matrigel, gelatin, or alginate. Artificial models usually use synthetic polymers made up of polyethene glycol, polylactic acid, and poly(vinyl acetate). Polymeric scaffolds are replicating 
the structure of the ECM very accurately, thus they are an essential tool to study cell-to-ECM interactions. Hydrophilic glass fibres are crucial models for designing 3D tumours and tracking cell migration, however, this model is still being explored. Organoids mimic the microenvironment of organs and are very useful for modelling human diseases by pluripotent stem cells derived from patients (Jensen and Teng, 2020).

The multicellular spheroids model includes techniques such as hanging drop microplates, magnetic levitation, and spheroid microplates. The last approach is especially unique due to its ability to grow freely without any scaffold. Spheroid microplates enable the growth of multicellular cultures because of the large volume. Moreover, cell growth has significant differences between cells grown as multicellular spheres and cultured in $2 \mathrm{D}$ culture. The cells from $3 \mathrm{D}$ culture showed multidrug resistance, displayed stem-like behaviours, and their motility was increased. The hanging drop method uses gravitation force to induce self-aggregation of cells that further make up spheroids. This approach offers high replicability of results. Magnetic levitation is performed by injecting magnetic nanoparticles into cells that induce cell aggregation to spheroids when exposed to magnetic force. This generates a concentrated environment where ECM can be synthesised, and further biochemical assays may be performed, i.e., western blotting (Jensen and Teng, 2020).

\section{METHODS FOR CELL LINE CHARACTERISATION}

Cell lines' characterisation is crucial to identifying cell line origin, purity, and features. The process of characterisation and authentication should include different assays related to specific (extra- and intracellular) markers. The researchers should confirm whether obtained cell lines meet their expectations because, during multiple passages, the cell line may lose its key characteristic features (Geraghty et al., 2014). Additionally, cell line characterisation helps to avoid common misidentification and contamination with mycoplasma. These problems are often ignored by the research community, which leads to modification of scientific data. Studies using misidentified or contaminated cell lines are not reproducible, and their results are uncertain and less valuable. Moreover, such research is not cost-effective (Geraghty et al., 2014; Almeida et al., 2016).

\section{Immunohistochemistry}

Immunohistochemistry (IHC) is a leading method for cancer diagnosis in clinical pathology. IHC uses monoclonal and polyclonal antibodies to identify specific antigens in specimens (Jensen et al., 2017). There are four formats of specimens used in IHC: paraffin-embedded, frozen, free-floating, and cytological. Out of these formats, the most commonly used is the paraffinembedded approach. The tissue sample is fixed in formalin to preserve proteins in vivo state as much as possible, thus fixation is the most significant step. Then the sample is processed in paraffin wax, which provides a sort of supporting media. After that, tissue fragments of $4 \mu \mathrm{m}$ thickness are dissected and placed in a water bath at the temperature of $45^{\circ} \mathrm{C}$. The specimen is laid on a microscope slide and dried at $37^{\circ} \mathrm{C}$ overnight for better adherence of tissue to the slide. The sample is rewaxed before immunohistochemical staining (Renshaw, 2017). IHC is one of the most widespread tools for assessing cells' features such as expression of hormonal receptors (ER and PR), EGFR receptor (HER2 neu) in breast cancer (Bonacho et al., 2020). IHC may also be used to mark epithelial cell characteristics in ovarian cancer by applying specific antibodies (EpCAM, CA125, and MOC-31) (O’Donnell et al., 2014).

\section{Western Blot}

Western blot (WB) is a commonly used method to separate and identify proteins. Initially, a mixture of proteins is separated during electrophoresis. Then, the proteins are transferred to the membrane, which is incubated with specific antibodies. Incubation is followed by washing which causes a rinse of unbounded antibodies. Antibodies bounded to proteins are detected and visualised on the membrane. The thickness of each band depends on the amount of protein (Mahmood and Yang, 2012). WB is useful while examining the expression of biochemical markers. For instance, prostate epithelial cells express various marker proteins during differentiation, thus their activity can be investigated by WB. It enables the characterisation of the molecular subtype of cell lines, including ones expressing CK18, CK 5, E-cadherin, or p63 (Wang et al., 2019). In ascending colon cancer, WB can be useful for the determination of the presence and size of insulinoma-associated protein 1 (INSM-1) from lysates. INSM-1 is a product of gene INSM-1 that regulates the expression of neuroendocrine markers (Shinji et al., 2019).

\section{Flow Cytometry}

Flow cytometry (FC) is a prominent method used in immunology, molecular biology, and cancer research. This approach utilises single or multiple laser light to analyse cells and particles suspended in buffered solution. Each particle undergoes analysis under visible light scatter and fluorescent assessment. Visible light scatters evaluated particles in the forward direction, which displays the comparative cell size and at $90^{\circ}$, which shows the cell's complexity and granularity. Fluorescent assessment includes cell transfection and fluorescent proteins' expression, staining with fluorescent dyes, or fluorescently conjugated antibodies. Visible light scatters independent of fluorescence measurement. The most common purpose of FC is immunophenotyping. It enables analysis of cell culture for various parameters, such as $\mathrm{T}$ and $\mathrm{B}$ cell markers, monocyte markers (CD14 and CD11b), NK cell markers (CD56 and CD161), activation markers (CD69 and CD25), memory markers (CD45RO and CD27), cytokines presence (IFN- $\gamma$, TNF- $\alpha$, and IL-2 define TH1 cells), and antigen-specific markers (MHC). Cell line's features can be analysed in terms of proliferation (markers Ki67 and CFSE) and apoptosis (the activity of caspases) (McKinnon, 2018). Like other methods, FC helps categorise cell lines according to the presence or absence of particular cell surface markers defining the origin of isolated cells (epithelial, mesenchymal, or stem cells) (Widowati et al., 2018). Moreover, FC enables the determination of the cell line's molecular subtype by analysing overexpression of receptors, such as HER2 or 
HER3 in breast cancer (Nushtaeva et al., 2019). FC serves as a straightforward tool for quick evaluation of stemness markers like aldehyde-dehydrogenase (ALDH) (Tusa et al., 2020). Moreover, FC is useful not only for immunophenotyping, it has an application assessment of cell apoptosis, viability, and cell cycle, for example in gastric cancer (Zhao et al., 2018).

\section{Immunocytochemistry and Immunofluorescence}

Immunocytochemistry (ICC) utilises labelling cells with antibodies to determine population homogeneity and molecular profile. This method visualises individual cells and enables evaluating the distribution of molecular markers in the cell culture. Immunocytochemistry includes cell morphology and exposes subcellular localisation of a particular antigen. The experiment should consist of the negative control (without primary antibody) and positive control (with a cell known to express given antigen) to determine staining propriety. Immunocytochemistry often uses fluorescently tagged secondary antibodies to reveal the primary antibody bounded to an epitope on the investigating molecule. A secondary antibody can detect the heavy chain of the primary antibody. This procedure utilises prolonged incubation for the primary antibody, followed by a few washes to remove the remaining antibodies. Then shorter incubation is applied for a secondary antibody with subsequent washing. Afterwards, the sample is processed under microscopy (Ziaeian et al., 2012). The immunocytochemical staining may unveil the cell lines' features, such as no ER, PR, or HER2 expression in breast cancer cell lines (Ghaderi et al., 2019). ICC is also useful to detect keratins' presence, for example, keratin 19 a biomarker for many tumours, including breast cancer (Shi et al., 2017; Sharma et al., 2019).

Immunofluorescence (IF) is a method of choice while working with adherent cell lines. It simplifies the isolation of the individual signal and cell lines usually are not vulnerable to damages, due to similar auto-fluorescence as they exhibit from tissue sections (Renshaw, 2017). The immunofluorescence is also a useful approach to reveal cytoskeleton structures like filaments, i.e., vimentin and cytokeratins (Lai et al., 2015), as in the case of pancreatic cancer (Ehlen et al., 2020).Immunofluorescence is often used to detect mycoplasma contamination by mycoplasmaspecific polyclonal or monoclonal antibodies (Freshney, 2010).

\section{Confocal Fluorescent Microscope}

A confocal fluorescence microscope serves as a great tool for assessments in cells and tissues. Confocal microscopes generate high-contrast images through optical sectioning. It is achieved by a high-resolution objective lens which produces optical sections thinner than $1 \mu \mathrm{m}$ without slicing the specimen. A single confocal image, also called a slice, is enough for quantification, although it is possible to use a series of confocal images to generate a $3 \mathrm{D}$ dataset. The $3 \mathrm{D}$ model enables the reconstruction and quantification of the whole sample volume. The use of fluorescent molecules is advantageous while assessing molecules' localisation from various cellular compartments (Jonkman et al., 2020). In practice, the confocal fluorescent microscope can be used to distinguish morphological differences, for example, between pericytes and embryonic fibroblasts. After fixation, cells are labelled with fluorescent dyes, and immunostained cells are imaged on the confocal microscope (Zhao et al., 2019).

\section{RT-qPCR}

Gene expression measurement in cultured cells by reverse transcription-quantitative real-time polymerase chain reaction (RT-qPCR) is an essential technique used in molecular biology and medical research (Van Peer et al., 2012). This tool provides the measurement of RNA levels through cDNA in a $\mathrm{qPCR}$ assay and monitors the amplification of targeted DNA samples by fluorescence of dyes used in the reaction. Fluorescence is equivalent to the amount of product yielded during the PCR cycling phase (Fowotade, 2018; Adams, 2020). Model systems can be subjected to inhibitors, stimulants, small interfering RNAs, and knockouts to investigate gene expression. Moreover, RTqPCR is commonly used as quality control to examine changes in expression during RNA sequencing (RNA-seq) (Adams, 2020). In the characterisation of cell lines, RT-qPCR can be used to investigate cancer stem cell markers, such as expression of clusters of differentiation (CD24, CD44, CD133, and CD166) (Shinji et al., 2019). This method also enables the detection of particular genes needed for cell line characterisation, for example, B2M and RPL29, in the case of tongue carcinoma cell line (Wang et al., 2017). RT-qPCR can be applied for the determination of epithelial-mesenchymal transition (EMT), which contributes to the migration property of cells. For this assessment, synthesis of primers for EMT (E-cadherin, N-cadherin, and Vimentin) and CSC markers (CD44v6, CD117, ALDH1A1, and Snail) is crucial (Deng et al., 2019).

\section{Karyotyping}

Karyotype analysis includes pairing and ordering all organisms' chromosomes, resulting in the genome-wide projection of the individual chromosomes. The preparation of karyotypes consists of staining, enabling exposure to chromosomes' structural characteristics (Raghavendra and Pullaiah, 2018). Karyotypes are often used to investigate the aberrations in chromosome numbers, chromosomal translocations, deletions, and inversions (Sampson and McGuire, 2014). For this reason, karyotyping is a cheap and popular method of choice to demonstrate changes in the cell line and reveals exciting features of cell lines, that have never been observed before (Geraghty et al., 2014; Wang et al., 2019).

\section{Next-Generation Sequencing}

There is an increasing demand for high throughput technologies for gene expression analysis of cell lines (Van Peer et al., 2012). In this instance, NGS provides comprehensive cell line characterisation taking into account transcriptome, proteome, metabolome, and genome. The most useful methods are wholegenome sequencing and whole-exome sequencing to describe cell lines' genomes. Transcriptome characterisation may be provided by assays using RNA, such as RNA-seq and MicroRNA sequencing. Cell lines' proteome is most commonly assessed by chromatin profiling and protein quantification (RPPA), whereas, 
metabolite profiling is used to describe the metabolome (Ghandi et al., 2019). Predictive markers for drug resistance, biomarkers for diagnostic purposes, and prognostic markers in lung cancer have been discovered and analysed by quantitative proteomic analysis (Hoi et al., 2017). Transcriptome analysis of breast cancer stem cells revealed pathways activated in CSCs, in particular, eIF2, eIF4, and ephrin. Transcriptome examination of breast CSCs also uncovered differential methylated DNA, histone modifications, and shed a light on tumour suppressor genes downregulated in CSCs (Li et al., 2018).

\section{CONCLUSION}

Primary cell lines are pivotal for cancer research and have significantly contributed to understanding tumour biology, molecular processes, oncogene activation, and gene expression of individual patients. Primary cancer cultures are crucial for conceptualising therapeutic targets that may serve for future drug development or personalised cancer therapy. Patient-derived samples are currently extensively used for the improvement of existing treatments in personalised medicine. Moreover, the combination of primary cancer cell lines with advanced techniques (such as NGS) is a prospective cancer research tool

\section{REFERENCES}

Adams, G. (2020). A beginner's guide to RT-PCR, qPCR and RT-qPCR. Biochemist $42,48-53$.

Ali, R., Samman, N., Al Zahrani, H., Nehdi, A., Rahman, S., Khan, A. L., et al. (2017). Isolation and characterization of a new naturally immortalized human breast carcinoma cell line, KAIMRC1. BMC Cancer 17, 1-13. doi: 10.1186/ s12885-017-3812-5

Almeida, J. L., Cole, K. D., and Plant, A. L. (2016). Standards for Cell Line Authentication and Beyond. PLoS Biol. 14, 1-9. doi: 10.1371/journal.pbio. 1002476

Alvarez, V. M., Von Der, Weid, I., Seldin, L., and Santos, A. L. S. (2006). Influence of growth conditions on the production of extracellular proteolytic enzymes in Paenibacillus peoriae NRRL BD-62 and Paenibacillus polymyxa SCE2. Lett. Appl. Microbiol. 43, 625-630. doi: 10.1111/j.1472-765X.2006.02 015.x

Bhogal, R. H., Hodson, J., Bartlett, D. C., Weston, C. J., Curbishley, S. M., Haughton, E., et al. (2011). Isolation of primary human hepatocytes from normal and diseased liver tissue: A one hundred liver experience. PLoS One 6, 1-8. doi: 10.1371/journal.pone.0018222

Bonacho, T., Rodrigues, F., and Liberal, J. (2020). Immunohistochemistry for diagnosis and prognosis of breast cancer: a review. Biotech. Histochem. 95:2.

Carter, M., and Shieh, J. C. (2010). Cell culture techniques. Guide Res. Tech. Neurosci. 2010:003. doi: 10.1017/cbo9780511841477.003

Casali, P. G., and Vyas, M. (2021). Data protection and research in the European Union: a major step forward, with a step back. Ann. Oncol. 32, 15-19. doi: 10.1016/j.annonc.2020.10.472

Cheung, P. F., Yip, C. W., Ng, L. W., Lo, K. W., Wong, N., Choy, K. W., et al. (2014). Establishment and characterization of a novel primary hepatocellular carcinoma cell line with metastatic ability in vivo. Cancer Cell Int. 14:103.

Dallaglio, K., Petrachi, T., Marconi, A., Truzzi, F., Roop, D. R., and Pincelli, C. (2013). Isolation and Characterization of Squamous Cell Carcinoma-Derived Stem-like Cells: Role in Tumor Formation. Int. J. Mol. Sci. 14, 19540-19555. doi: 10.3390/ijms141019540

Deng, J., Bai, X., Feng, X., Ni, J., Beretov, J., Graham, P., et al. (2019). Inhibition of $\mathrm{PI} 3 \mathrm{~K} / \mathrm{Akt} / \mathrm{mTOR}$ signaling pathway alleviates ovarian cancer chemoresistance through reversing epithelial-mesenchymal transition and decreasing cancer that leaves the door open to identify novel biomarkers and oncogenes. Knowing the limitations and benefits of primary cell lines, scientists should pay more attention to the choice of model they will work on. It is important to also use established cell lines according to the purpose of the planned experiment. Nevertheless, the culture of primary cell lines is a key element in research towards personalised medicine, which is the future of cancer treatment.

\section{AUTHOR CONTRIBUTIONS}

MR and OP wrote the manuscript with support from MM, IP, WMS, and TT. MR and OP declare an equal co-authorship. MM and IP participate in drafting the article and helped supervised the article. WMS and TT make substantial contributions to the conception and design of the article and give final approval of the version to be submitted and any revised version.

\section{FUNDING}

The project was funded from the resources of the National Science Centre, grant no. 2019/33/B/NZ5/01989 to TT (PI).

stem cell marker expression. BMC Cancer 19, 1-12. doi: 10.1186/s12885-0195824-9

Ehlen, L., Arndt, J., Treue, D., Bischoff, P., Loch, F. N., Hahn, E. M., et al. (2020). Novel methods for in vitro modeling of pancreatic cancer reveal important aspects for successful primary cell culture. BMC Cancer 20, 1-13. doi: 10.1186/ s12885-020-06929-8

Failli, A., Consolini, R., Legitimo, A., Spisni, R., Castagna, M., Romanini, A., et al. (2009). The challenge of culturing human colorectal tumor cells: Establishment of a cell culture model by the comparison of different methodological approaches. Tumori 95, 343-347. doi: 10.1177/0300891609095 00312

Faridi, N., Bathaie, S. Z., Abroun, S., Farzaneh, P., Karbasian, H., Tamanoi, F., et al. (2018). Isolation and characterization of the primary epithelial breast cancer cells and the adjacent normal epithelial cells from Iranian women's breast cancer tumors. Cytotechnology 70, 625-639. doi: 10.1007/s10616-017-0159-3

Fowotade, A. (2018). Normalization of Gene Expression by Quantitative RT-PCR in Human Cell Line: comparison of 12 Endogenous Reference Genes. Ethiop. J. Health Sci. 28:6.

Freshney, I. R. (2010). Culture of Animal Cells, Vol. 5. Hoboken, NJ: John Wiley \& Sons.

Geraghty, R. J., Capes-Davis, A., Davis, J. M., Downward, J., Freshney, R. I., Knezevic, I., et al. (2014). Guidelines for the use of cell lines in biomedical research. Br. J. Cancer 111, 1021-1046. doi: 10.1038/bjc.2014.166

Ghaderi, F., Mehdipour, F., Hosseini, A., Talei, A., and Ghaderi, A. (2019). Establishment and characterization of a new triple negative breast cancer cell line from an Iranian breast cancer tissue. Asian Pacific J. Cancer Prevent. 20, 1683-1689. doi: 10.31557/APJCP.2019.20.6.1683

Ghandi, M., Huang, F. W., Jané-Valbuena, J., Kryukov, G. V., Lo, C. C., McDonald, E. R., et al. (2019). Next-generation characterization of the Cancer Cell Line Encyclopedia. Nature 569, 503-508. doi: 10.1038/s41586-0191186-3

Gillooly, J. F., Hayward, A., Hou, C., and Gordon Burleigh, J. (2012). Explaining differences in the lifespan and replicative capacity of cells: A general model and comparative analysis of vertebrates. Proc. R. Soc. B Biol. Sci. 279, 3976-3980. doi: $10.1098 / \mathrm{rspb} .2012 .1129$

Hoi, C., Cheung, Y., and Juan, H. (2017). Quantitative proteomics in lung cancer. J. Biomed. Sci. 24, 1-11. doi: 10.1186/s12929-017-0343-y 
Horner, R., Gassner, J. G. M. V., Kluge, M., Tang, P., Lippert, S., Hillebrandt, K. H., et al. (2019). Impact of Percoll purification on isolation of primary human hepatocytes. Sci. Rep. 9, 2-11. doi: 10.1038/s41598-019-43042-8

Hubel, A., Spindler, R., and Skubitz, A. P. N. (2014). Storage of human biospecimens: Selection of the optimal storage temperature. Biopreserv. Biobank. 12, 165-175. doi: 10.1089/bio.2013.0084

Hudu, S. A., Alshrari, A. S., Syahida, A., and Sekawi, Z. (2016). Cell culture, technology: Enhancing the culture of diagnosing human diseases. J. Clin. Diagnost. Res. 10, DE01-DE05. doi: 10.7860/JCDR/2016/15837.7460

Ishikawa, T. (2017). Next-generation sequencing traces human induced pluripotent stem cell lines clonally generated from heterogeneous cancer tissue. World J. Stem Cells 9, 77-88. doi: 10.4252/wjsc.v9.i5.77

Jedrzejczak-Silicka, M. (2017). "History of Cell Culture," in New Insights into Cell Culture Technology, eds S. Joghi and T. Gowder (London: IntechOpen).

Jensen, C., and Teng, Y. (2020). Is It Time to Start Transitioning From 2D to 3D Cell Culture? Front. Mol. Biosci. 7, 1-15. doi: 10.3389/fmolb.2020.00033

Jensen, K., Krusenstjerna-hafstrøm, R., Lohse, J., and Petersen, K. H. (2017). A novel quantitative immunohistochemistry method for precise protein measurements directly in formalin-fixed, paraffin-embedded specimens: analytical performance measuring HER2. Modern Pathol. 30, 180-193. doi: 10.1038/modpathol.2016.176

Jonkman, J., Brown, C. M., Wright, G. D., Anderson, K. I., and North, A. J. (2020). Tutorial: guidance for quantitative confocal microscopy. Nat. Prot. 15, 1585-1611. doi: 10.1038/s41596-020-0313-9

Kapałczyńska, M., Kolenda, T., Przybyła, W., Zajączkowska, M., Teresiak, A., Filas, V., et al. (2016). 2D and 3D cell cultures - a comparison of different. Archiv. Med. Sci. 14, 910-919.

Knijn, N., Simmer, F., and Nagtegaal, I. D. (2015). Recommendations for reporting histopathology studies: A proposal. Virchows Archiv. 466, 611-615. doi: 10. 1007/s00428-015-1762-3

Kodack, D. P., Farago, A. F., Dastur, A., Held, M. A., Dardaei, L., Friboulet, L., et al. (2017). Primary Patient-Derived Cancer Cells and Their Potential for Personalized Cancer Patient Care. Cell Rep. 21, 3298-3309. doi: 10.1016/j. celrep.2017.11.051

Kurashina, Y., Imashiro, C., Hirano, M., Kuribara, T., Totani, K., Ohnuma, K., et al. (2019). Enzyme-free release of adhered cells from standard culture dishes using intermittent ultrasonic traveling waves. Comm. Biol. 2, 1-11. doi: 10.1038/ s42003-019-0638-5

Lai, Z. W., Bolm, L., Fuellgraf, H., Biniossek, M. L., Makowiec, F., Hopt, U. T., et al. (2015). Characterization of various cell lines from different ampullary cancer subtypes and cancer associated fibroblast-mediated responses. BMC Cancer 16, 1-17. doi: 10.1186/s12885-016-2193-5

Lauro, S., Onesti, E., Righini, R., and Marchetti, P. (2014). The use of bevacizumab in non-small cell lung cancer: An update. Anticancer Res. 34, 1537-1546.

Ledur, P. F., Onzi, G. R., Zong, H., and Lenz, G. (2017). Culture conditions defining glioblastoma cells behavior: what is the impact for novel discoveries? Oncotarget 8, 69185-69197. doi: 10.18632/oncotarget.20193

Leithner, K., Wohlkoenig, C., Stacher, E., Lindenmann, J., Hofmann, N. A., Gallé, B., et al. (2014). Hypoxia increases membrane metallo-endopeptidase expression in a novel lung cancer ex vivo model - role of tumor stroma cells. BMC Cancer 14, 1-13. doi: 10.1186/1471-2407-14-40

Li, G., Wang, D., Ma, W., An, K., Liu, Z., Wang, X., et al. (2018). Transcriptomic and epigenetic analysis of breast cancer stem cells. Epigenomics 10, 765-783. doi: $10.2217 /$ epi-2018-0008

Mahmood, T., and Yang, P. C. (2012). Western blot: Technique, theory, and trouble shooting. North Am. J. Med. Sci. 4, 429-434. doi: 10.4103/1947-2714.100998

McKinnon, K. M. (2018). Flow cytometry: an overview. Curr. Protocols Immunol. 2018:623. doi: 10.1007/978-94-017-0623-0_1

Meltzer, P., Leibovitz, A., Dalton, W., Villar, H., Kute, T., Davis, J., et al. (1991). Establishment of two new cell lines derived from human breast carcinomas with her-2/neu amplification. Br. J. Cancer 63, 727-735. doi: 10.1038/bjc.1991.164

Miserocchi, G., Mercatali, L., Liverani, C., De Vita, A., Spadazzi, C., Pieri, F., et al. (2017). Management and potentialities of primary cancer cultures in preclinical and translational studies. J. Translat. Med. 15, 1-16. doi: 10.1186/s12967-0171328-z

Mitra, A., Mishra, L., and Li, S. (2013). Technologies for deriving primary tumor cells for use in personalized cancer therapy. Trends Biotechnol. 31, 347-354. doi: 10.1016/j.tibtech.2013.03.006
Nushtaeva, A. A., Karpushina, A. A., Ermakov, M. S., Gulyaeva, L. F., Gerasimov, A. V., Sidorov, S. V., et al. (2019). Establishment of primary human breast cancer cell lines using "pulsed hypoxia" method and development of metastatic tumor model in immunodeficient mice. Cancer Cell International. 19, 1-19. doi: 10.1186/s12935-019-0766-5

O’Donnell, R. L., Mccormick, A., Mukhopadhyay, A., Woodhouse, L. C., Moat, M., Grundy, A., et al. (2014). The Use of Ovarian Cancer Cells from Patients Undergoing Surgery to Generate Primary Cultures Capable of Undergoing Functional Analysis. PLoS One 9, 1-9. doi: 10.1371/journal.pone.0090604

Pandrangi, S. L., Raju Bagadi, S. A., Sinha, N. K., Kumar, M., Dada, R., Lakhanpal, M., et al. (2014). Establishment and characterization of two primary breast cancer cell lines from young Indian breast cancer patients: Mutation analysis. Cancer Cell International. 14, 1-20. doi: 10.1186/1475-2867-14-14

Patel, A. K., and Rajput, S. P. S. (2019). A review on human biological materialtypes, uses, storage and disposal. Material. Today Proc. 18, 5133-5140. doi: 10.1016/j.matpr.2019.07.510

Penderecka, K., Ibbs, M., Kaluzna, A., Lewandowska, A., Marszalek, A., Mackiewicz, A., et al. (2020). Implementation of a dynamic culture condition to the heterotypic 3D breast cancer model. J. Biomed. Material. Res. Part B Appl. Biomat. 108, 1186-1197. doi: 10.1002/jbm.b.34468

Petrini, C. (2012). Ethical and legal considerations regarding the ownership and commercial use of human biological materials and their derivatives. J. Blood Med. 87:6134. doi: 10.2147/jbm.s36134

Phuc, P., Van, Khuong, T. T. T., Dong, L., Van, Kiet, T. D., et al. (2010). Isolation and characterization of breast cancer stem cells from malignant tumours in Vietnamese women. J. Cell Anim. Biol. 4, 163-169.

Pribyl, L. J., Coughlin, K. A., Sueblinvong, T., Shields, K., Iizuka, Y., Downs, L. S., et al. (2014). Method for Obtaining Primary Ovarian Cancer Cells From Solid Specimens. J. Vis. Exp. 84, e51581. doi: 10.3791/51581

Qiu, X., De Jesus, J., Pennell, M., Troiani, M., and Haun, J. B. (2015). Microfluidic device for mechanical dissociation of cancer cell aggregates into single cells. $L a b$. Chip 15, 339-350. doi: 10.1039/c4lc01126k

Qiu, X., Huang, J., Westerhof, T. M., Lombardo, J. A., Henrikson, M., Pennell, M., et al. (2018). Microfluidic channel optimization to improve hydrodynamic dissociation of cell aggregates and tissue. Sci. Rep. August 2017, 1-10. doi: 10.1038/s41598-018-20931-y

Raghavendra, P., and Pullaiah, T. (2018). Advancements in Genetic Applications for Cellular and Molecular Diagnostics. Adv. Cell Mole. Diag. 2018, 57-84. doi: 10.1016/b978-0-12-813679-9.00003-8

Renshaw, S. (2017). Immunohistochemistry and immunocytochemistry. Immunohistochem. Essent. Method 2017:9781118717769. doi: 10.1002/9781 118717769.ch3

Sampson, B., and McGuire, A. (2014). "Genetics and the Molecular Autopsy," in Pathobiology of Human Disease: A Dynamic Encyclopedia of Disease Mechanisms, eds L. M. McManus and N. Richard (Amsterdam: Elsevier Inc), doi: 10.1016/B978-0-12-386456-7.06707-1

Sharma, P., Alsharif, S., Bursch, K., Parvathaneni, S., Anastasakis, D. G., Chahine, J., et al. (2019). Keratin 19 regulates cell cycle pathway and sensitivity of breast cancer cells to CDK inhibitors. Sci. Rep. 9, 1-12. doi: 10.1038/s41598-01951195-9

Shepherd, T. G., Thériault, B. L., Campbell, E. J., and Nachtigal, M. W. (2007). Primary culture of ovarian surface epithelial cells and ascites-derived ovarian cancer cells from patients. Nat. Protocols 1, 2643-2649. doi: 10.1038/nprot.2006. 328

Shi, A. P., Fan, Z. M., Ma, K. W., Jiang, Y. F., Wang, L., Zhang, K. W., et al. (2017). Isolation and characterization of adult mammary stem cells from breast cancer-adjacent tissues. Oncol. Lett. 14, 2894-2902. doi: 10.3892/ol.2017.6485

Shinji, S., Sasaki, N., Yamada, T., Koizumi, M., Ohta, R., Matsuda, A., et al. (2019). Establishment and characterization of a novel neuroendocrine carcinoma cell line derived from a human ascending colon tumor. Cancer Sci. 110, 3708-3717. doi: $10.1111 /$ cas. 14221

Simon, T., Coquerel, B., Petit, A., Kassim, Y., Demange, E., Le Cerf, D., et al. (2014). Direct Effect of Bevacizumab on Glioblastoma Cell Lines In Vitro. NeuroMole. Med. 16, 752-771. doi: 10.1007/s12017-014-8324-8

Tusa, I., Cheloni, G., Poteti, M., Silvano, A., Tubita, A., Lombardi, Z., et al. (2020). In Vitro Comparison of the Effects of Imatinib and Ponatinib on Chronic Myeloid Leukemia Progenitor/Stem Cell Features. Targeted Oncol. 15, 659-671. doi: $10.1007 / \mathrm{s} 11523-020-00741-\mathrm{x}$ 
Van Peer, G., Mestdagh, P., and Vandesompele, J. (2012). Accurate RT-qPCR gene expression analysis on cell culture lysates. Sci. Rep. 2, 1-5. doi: 10.1038/ srep00222

Vázquez, S. M., Mladovan, A., Garbovesky, C., Baldi, A., and Lüthy, I. A. (2004). Three Novel Hormone-Responsive Cell Lines Derived from Primary Human Breast Carcinomas: Functional Characterization. J. Cell. Physiol. 199, 460-469. doi: $10.1002 /$ jcp. 10466

Verma, A., Verma, M., and Singh, A. (2020). Animal tissue culture principles and applications. Anim. Biotechnol. 2020, 269-293.

Villa, P. L., Jackson, R., Eade, S., Escott, N., and Zehbe, I. (2018). Isolation of Biopsy-Derived, Human Cervical Keratinocytes Propagated as Monolayer and Organoid Cultures. Sci. Rep. 8, 1-10. doi: 10.1038/s41598-018-36 $150-4$

Volovitz, I., Shapira, N., Ezer, H., Gafni, A., Lustgarten, M., Alter, T., et al. (2016). A non - aggressive, highly efficient, enzymatic method for dissociation of human brain - tumors and brain - tissues to viable single - cells. BMC Neurosci. 2016, 1-10. doi: 10.1186/s12868-016-0262-y

Wang, R., Chu, G. C. Y., Wang, X., Wu, J. B., Hu, P., Multani, A. S., et al. (2019). Establishment and characterization of a prostate cancer cell line from a prostatectomy specimen for the study of cellular interaction. Internat. J. Cancer 145, 2249-2259. doi: 10.1002/ijc.32370

Wang, X., Liu, X., Liu, C., Ren, M., Gao, S., Zhao, G., et al. (2017). Validation of reference genes for the normalization of RT-qPCR expression studies in human tongue carcinoma cell lines and tissue. Oncol. Lett. 13, 3951-3957. doi: $10.3892 / \mathrm{ol} .2017 .5887$

Weigand, A., Boos, A. M., Tasbihi, K., Beier, J. P., Dalton, P. D., Schrauder, M., et al. (2016). Selective isolation and characterization of primary cells from normal breast and tumors reveal plasticity of adipose derived stem cells. Breast Cancer Res. 18, 1-20. doi: 10.1186/s13058-016-0688-2

Widowati, W., Heriady, Y., Laksmitawati, D. R., Jasaputra, D. K., Wargasetia, T. L., Rizal, R., et al. (2018). Isolation, characterization and proliferation of cancer cells from breast cancer patients. Acta Informat. Med. 26, 240-244. doi: 10.5455/aim.2018.26.240-244
Yap, N. Y., Ong, T. A., Morais, C., Pailoor, J., Gobe, G. C., and Rajandram, R. (2019). Establishment of epithelial and fibroblast cell cultures and cell lines from primary renal cancer nephrectomies. Cell Biol. Internat. 43, 715-725. doi: 10.1002/cbin.11150

Zazo, S., González-Alonso, P., Martín-Aparicio, E., Chamizo, C., Cristóbal, I., Arpí, O., et al. (2016). Generation, characterization, and maintenance of trastuzumab-resistant HER2+ breast cancer cell lines. Am. J. Cancer Res. 6, 2661-2678.

Zhao, H., Darden, J., and Chappell, J. C. (2019). Establishment and Characterization of an Embryonic Pericyte Cell Line. Physiol. Behav. 176, 139-148. doi: 10.1111/micc.12461.Establishment

Zhao, Y., Liu, Y., Lin, L., Huang, Q., He, W., Zhang, S., et al. (2018). The lncRNA MACC1-AS1 promotes gastric cancer cell metabolic plasticity via AMPK/Lin28 mediated mRNA stability of MACC1. Mole. Cancer 17, 1-16.

Ziaeian, B., Nourse, J. L., Palmer, T., Schwartz, P. H., and Flanagan, L. A. (2012). Immunocytochemical Analysis of Human Stem Cells. Hum. Stem Cell Manual. 2012:385473. doi: 10.1016/B978-0-12-385473-5.00016-3

Zubeldia-Plazaola, A., Ametller, E., Mancino, M., de Puig, M. P., López-Plana, A., Guzman, F., et al. (2015). Comparison of methods for the isolation of human breast epithelial and myoepithelial cells. Front. Cell Dev. Biol. 3, 1-9. doi: $10.3389 /$ fcell.2015.00032

Conflict of Interest: The authors declare that the research was conducted in the absence of any commercial or financial relationships that could be construed as a potential conflict of interest.

Copyright (c) 2021 Richter, Piwocka, Musielak, Piotrowski, Suchorska and Trzeciak. This is an open-access article distributed under the terms of the Creative Commons Attribution License (CC BY). The use, distribution or reproduction in other forums is permitted, provided the original author(s) and the copyright owner(s) are credited and that the original publication in this journal is cited, in accordance with accepted academic practice. No use, distribution or reproduction is permitted which does not comply with these terms. 